\title{
The Gluten Gene: Unlocking the Understanding of Gluten Sensitivity and Intolerance
}

This article was published in the following Dove Press journal:

The Application of Clinical Genetics

\author{
Nastaran Asri (iD) \\ Mohammad Rostami-Nejad ${ }^{2}$ \\ Robert P Anderson ${ }^{3}$ \\ Kamran Rostami (D) ${ }^{4}$ \\ 'Basic and Molecular Epidemiology of \\ Gastrointestinal Disorders Research \\ Center, Research Institute for \\ Gastroenterology and Liver Diseases, \\ Shahid Beheshti University of Medical \\ Sciences, Tehran, Iran; ${ }^{2}$ Gastroenterology \\ and Liver Diseases Research Center, \\ Research Institute for Gastroenterology \\ and Liver Diseases, Shahid Beheshti \\ University of Medical Sciences, Tehran, \\ Iran; ${ }^{3}$ Wesley Medical Research - The \\ Wesley Hospital, Brisbane, Queensland, \\ Australia; ${ }^{4}$ Department of \\ Gastroenterology, MidCentral DHB, \\ Palmerston North, New Zealand
}

\begin{abstract}
Wheat flour is one of the most important food ingredients containing several essential nutrients including proteins. Gluten is one of the major protein components of wheat consisted of glutenin (encoded on chromosome 1) and gliadin (encoded on chromosome 1 and 6) and there are around hundred genes encoding it in wheat. Gluten proteins have the ability of eliciting the pathogenic immune responses and hypersensitivity reactions in susceptible individuals called "gluten-related disorders (GRDs)", which include celiac disease (CD), wheat allergy (WA), and non-celiac gluten sensitivity (NCGS). Currently removing gluten from the diet is the only effective treatment for mentioned GRDs and studies for the appropriate and alternative therapeutic approaches are ongoing. Accordingly, several genetic studies have focused on breeding wheat with low immunological properties through gene editing methods. The present review considers genetic characteristics of gluten protein components, focusing on their role in the incidence of gluten-related diseases, and genetic modifications conducted to produce wheat with less immunological properties.
\end{abstract}

Keywords: gliadin, glutenin, genetic loci, wheat allergy, celiac disease, non-celiac gluten sensitivity

\section{Introduction}

Gluten-containing grains are essential food ingredients, consumed in most parts of the world. ${ }^{1,2}$ Owing to their importance and thanks to their ability to grow in different climatic areas, wheat cereals were among the first crops to be cultivated (established in the "Fertile Crescent", such as modern Turkey, Iraq and Iran) and their importance has increased significantly over time. ${ }^{3-6}$ The complex genome of Triticum aestivum L. is arranged into three subgenomes, A, B, and D, each contains seven pairs of chromosomes. ${ }^{7,8}$ However, the ability of wheat to adapt to different eco-climatic conditions and deliberate breeding for specific traits have led to the emergence of varieties with different characteristics. ${ }^{8}$ Accordingly, evidence showed that changes in the environmental conditions (such as temperature, water, and fertilizer situations) could influence the expression of gluten genes in wheat. ${ }^{9}$

Wheat (Triticum aestivum L. $2 \mathrm{n}=6 \times=42)$ flour is composed of starch $(\sim 70$ $75 \%$ : main component), proteins $(\sim 10-15 \%)$, lipids $(\sim 2 \%)$, minerals $(\sim 2 \%)$, that convey substantial nutritional benefits to humans. ${ }^{10}$ Gluten is one of the major protein components of wheat ( $\sim 80 \%$ of the total proteins), which is specifically expressed in the developing grains and provides a source of nitrogen for germination and seedling growth. ${ }^{4,11-13}$ Gluten is composed of storage proteins including glutenin and gliadin and is the term applied to the viscoelastic matrix formed when
Correspondence: Kamran Rostami MidCentral DHB, 50 Ruahine Street, Roslyn, Palmerston North, 4442, New Zealand

Email Kamran.Rostami@midcentraldhb. govt.nz
The Application of Clinical Genetics 2021:14 37-50

DovePress in $D$ 
these proteins are mixed with water. There are around hundred of genes encoding gluten proteins in wheat. ${ }^{14-16}$ In general, wheat proteins are divided into water/saltsoluble and insoluble categories, of which gliadins and glutenins are insoluble components. ${ }^{17}$ As gliadins influence the extensibility and viscous nature and glutenins are responsible for the elasticity and strength of dough, gluten is known as the main factor in determining the quality of the baked products and processed foods' texture and flavor. ${ }^{18-20}$ Due to the high amount of proline (P) and glutamine (Q) residues in gluten, T.B. Osborne, the father of plant protein chemistry, called it "prolamine". 4,11,21 Accordingly, gliadin and glutenin are known as prolamin I and II, respectively. ${ }^{22}$ Prolamines in other cereals include secalin in rye, hordein in barley, avenins in oats, zeins in corn, but the medical use of the term "gluten" has evolved to include only those prolamines implicated in human disease. $^{23}$

Despite the numerous benefits of wheat, gluten proteins have the ability of eliciting the pathogenic immune responses and hypersensitivity reactions in susceptible individuals known as "gluten-related disorders (GRDs)". 4,23,24 GRDs encompasses three major types of diseases: celiac disease (CD), wheat allergy (WA) and non-celiac gluten sensitivity (NCGS) that affect around $1-7 \%$ of people worldwide. ${ }^{4,25-27}$ These are, biologically, different diseases with distinct immune, allergic, and possibly non-immune etiologies for which gluten or wheat flour is a common triggering factor that will be discussed in detail below. ${ }^{28}$

Nevertheless, numerous studies, based on findings showing that avenins alone do not induce immune responses in most $\mathrm{CD}$ patients and symptomatically tolerated by them, point to the safety of adding oats to their diet. $^{29-32}$ In this regard, however, Hardy et $\mathrm{al}^{33}$ in their in vivo study on 73 biopsy-confirmed HLA-DQ2.5+ CD patients showed that the ingestion of oats ( $100 \mathrm{~g} /$ day) for 3 days mobilizes polyclonal avenin-specific T-cells in blood in fewer than $10 \%$ of studied patients. Half of the patients had at least one digestive symptom during this challenge, which was due to a high daily intake of oats $(100 \mathrm{~g})$ and a high amount of fiber in them. Moreover, they reported that these T-cells were cross-reactive against avenin and hordein, and oral challenge with barley (and not wheat or rye) could stimulate these T-cells more efficiently than oats. They concluded that daily consumption of up to $100 \mathrm{~g}$ uncontaminated oats is insufficient to cause clinical relapse in $\mathrm{CD}$ patients. ${ }^{33}$ A plausible explanation for oats having low immune-toxicity is their low proline content and lack of proteolytically resistant peptides with more than 10 amino acid residues. ${ }^{33,34}$

This review aims to provide a thorough overview of genetic characteristics of gluten protein components, their role in the incidence of various gluten-associated diseases, and genetic modifications that could reduce the immunogenic properties of gluten and lead to wheat improvement.

\section{Method}

In general, searches are developed in PubMed, Google Scholar, MEDLINE, and SCOPUS databases from September 1987 to September 2020. The following terms, alone or in combination, were searched: "gluten content", "gliadin chromosomal locations", "glutenin chromosomal locations", "celiac immunogenic peptides", "wheat allergy immunogenic peptides", "immunogenic peptides and non-celiac gluten sensitivity", "toxic gluten", and "gluten genetic manipulations".

\section{Gliadin Components and Genetic Characteristics}

Gliadin is a combination of monomeric proteins that makes up about $30 \%$ of total flour proteins. ${ }^{4,35,36}$ Polyacrylamide gel electrophoresis at acidic $\mathrm{pH}(\mathrm{pH}=$ 3.1) shows four major groups called $\alpha-(25-35 \mathrm{kDa}), \beta-$ $(30-35 \mathrm{kDa}), \gamma-(35-40 \mathrm{kDa})$, and $\omega-(55-75 \mathrm{kDa})$ gliadins. ${ }^{2,4,8,37}$ As $\alpha$ - and $\beta$-gliadins have several similarities in their structure and number of amino acid residues, they are usually grouped and collectively named as $\alpha$ gliadins. ${ }^{8,38} \alpha / \beta$ - and $\gamma$-subunits are considered to be the major components of gliadins, and $\omega$-gliadin is lower. ${ }^{39} \mathrm{In}$ addition, the $\omega$ - gliadin differs in amino acid composition from those of the $\alpha$ - and $\gamma$-gliadins. ${ }^{4,11}$ Moreover, according to the Shewry classification based on the presence of sulfur-containing amino acids, gliadin subunits are divided into S-rich $(\alpha / \beta$ - and $\gamma-)$ and S-poor $(\omega-)$ gliadins. ${ }^{11}$

The gliadin is encoded by multigene families. ${ }^{40}$ Different reports on the chromosomal location showed that gliadin encoding genes are found on the short arm of the homoeologous group 1 (Gli-A1, $-B 1$ and $-D 1$ loci) and 6 (Gli-A2, - B2 and -D2 loci) chromosomes. ${ }^{2}$ Each of these loci contains multiple alleles and so far, more than 30 allelic variants have been identified for some Gli loci. ${ }^{2,37}$ Gli-1 genes encode $\gamma$ - and $\omega$-gliadins and Gli-2 genes encode the $\alpha$ - $/ \beta$ - and some of the $\gamma$-gliadins (Figure 1 ). ${ }^{34}$ There are also 

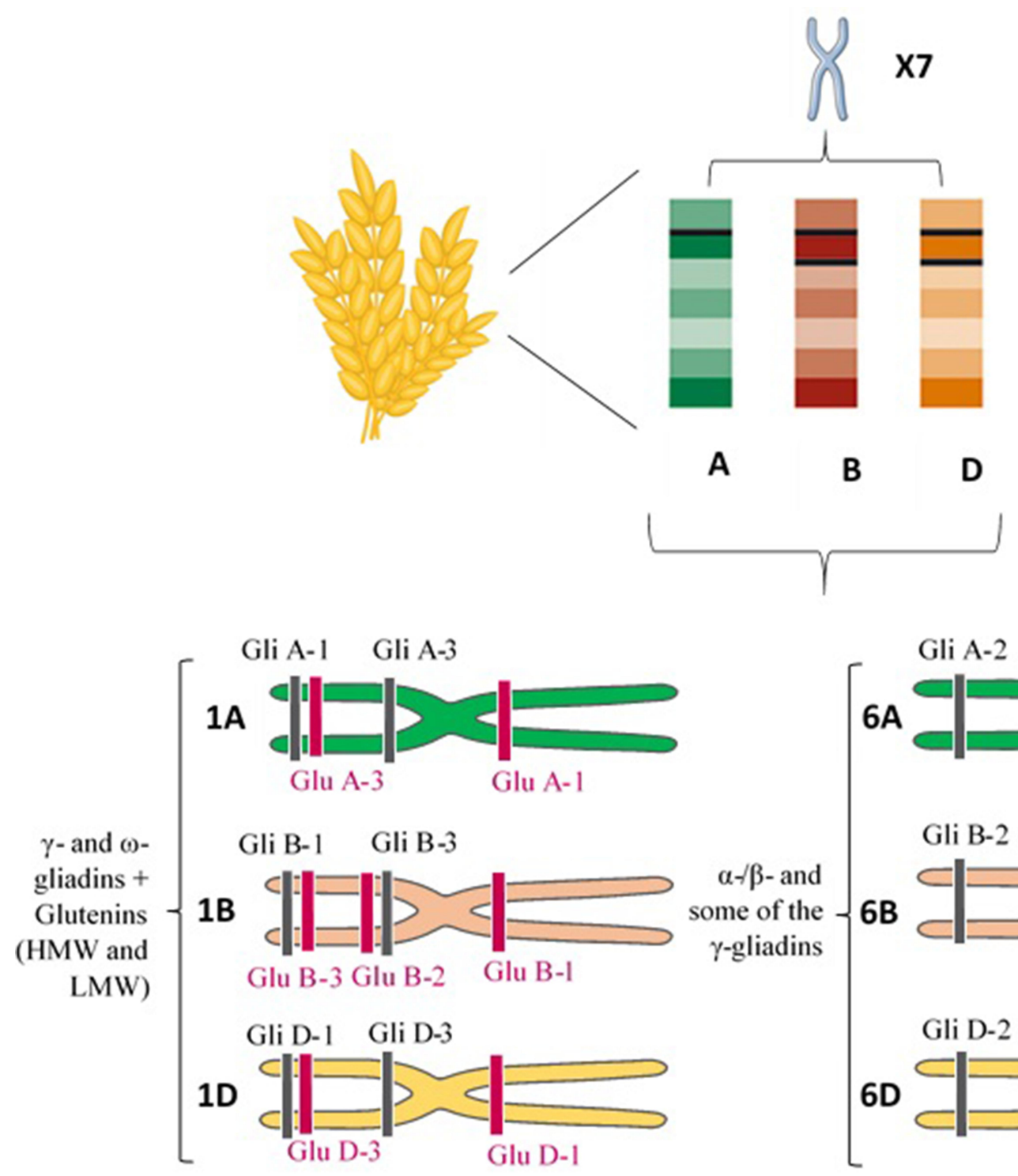

\section{$\alpha-\beta-$ and some of the $\gamma$-gliadins}

6B

Gli A-2

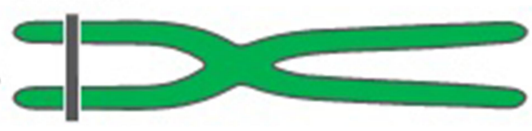

Gli B-2

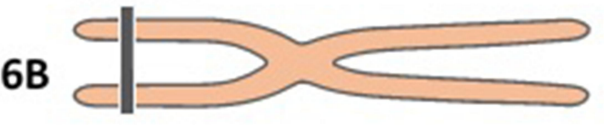

Gli D-2

6D

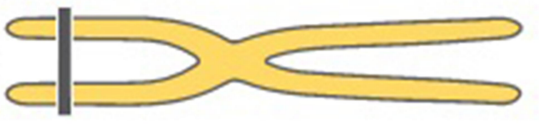

Figure I Chromosome site of different gluten constituents. Short arm of the homoeologous group I (Gli-AI, -BI and -DI loci) and 6 (Gli-A2, -B2 and -D2 loci) chromosomes encode $\gamma$ - and $\omega$-gliadins, and $\alpha$-/ $\beta$ - and some of the $\gamma$-gliadins, respectively. Glu-AI, BI, and DI loci (long arm) and Glu-A3, Glu-B3, and Glu-D3 loci (short arm) of the homoeologous group I chromosomes also encode the HMW-GS and LMW-GS subunits of glutenin, respectively.

Abbreviations: HMW, high molecular weight; LMW, low molecular weight.

some minor gliadin loci located on 1AS (Gli-A3, - A5 and $A 6), 1 \mathrm{BS}$ (Gli-B3 and -B5) and 1DS (Gli-D4 and -D6). ${ }^{41}$

$\alpha$-gliadins are the most abundant storage proteins in cereal and several gene copy numbers (from 25 to 150) have been reported for them in haploid genome. ${ }^{4,42-45}$ The $\alpha$-gliadin genes originated from the D sub-genome of wheat and contribute the most immunogenic T-cell stimulatory peptides in wheat gluten for the $90 \%$ of CD patients who are positive for the HLA-DQ2.5 genotype. ${ }^{42,46,47}$ However, the base substitution of glutamine codon (CAA) to a stop codon (TAA) can potentially cause inactivation of almost $50 \%$ of the $\alpha$-gliadin genes. ${ }^{20}$

\section{Glutenin Components and Genetic Characteristics}

The glutenin, which represents $50 \%$ of total flour proteins, consists of huge polymeric proteins linked through interand intramolecular disulfide bonds and are among the largest protein molecules in nature. ${ }^{2,14,36,48,49}$ Its separation by Sodium dodecyl sulfate-polyacrylamide gel electrophoresis (SDS-PAGE) shows high and low molecular weight (HMW-GS vs LMW-GS) subunits, which are 75 to $120 \mathrm{kDa}$ and 30 to $74 \mathrm{kDa}$, respectively. ${ }^{4,36,50}$ LMW-GS accounts for $\sim 60 \%$ of the glutenins and has a greater and more favorable impact on the properties of the dough than 
HMW-GS. ${ }^{51,52}$ HMW-GS is grouped into $\mathrm{x}$ - and y-type subunits based on its electrophoretic mobility and molecular mass. ${ }^{4,53}$ LMW-GS, which is similar to $\gamma$ - gliadins in size and structure, is subdivided into B-, C-, and D-type subunits (differ from A, B and D genomes of wheat) basis on their isoelectric point (PI) and electrophoretic mobility (B-type is the major group). ${ }^{36,52}$ The LMW-GS can also be classified based on the first $\mathrm{N}$-terminal amino acid residue into m-type (Methionine), s-type (Serine) and i-type (Isoleucine) subclasses. ${ }^{4,52}$

The HMW-GS and LMW-GS genes are located on the $G l u-A 1, B 1$, and $D 1$ loci (long arm) and Glu-A3, Glu-B3, and Glu-D3 loci (short arm) of the homoeologous group 1 chromosomes, respectively (Figure 1). ${ }^{52,54}$ The Glu-1 loci have multiple alleles and each of these loci includes two genes related to $\mathrm{x}$ - and $\mathrm{y}$-type subunits. ${ }^{54}$ The genes encoding LMW-GS are more complex and each Glu-3 loci contain several genes and each gene has two or more alleles. ${ }^{55,56}$ Genomic studies revealed that Glu-3 loci are linked to Gli-1 loci, and Gli-1 loci encode LMWGS in addition to $\gamma$ - and $\omega$-gliadin genes. ${ }^{4}$ Accordingly, the $\mathrm{C}$ and D subunits of LMW-GS are very similar in sequence to $\alpha-/ \gamma$ - and $\omega$-gliadins, respectively. ${ }^{36} \mathrm{LMW}-$ GS and HMW-GS contribute peptides that are immunogenic in CD patients who carry the less common HLADQ2.2 and DQ8 genotypes. ${ }^{57}$

\section{Gluten Protein and the Pathogenesis of Various GRDs Celiac Disease (CD)}

Studies reported that $\mathrm{CD}$ has a prevalence of approximately $1-3 \%$ in the general population worldwide especially in Western societies. ${ }^{58,59} \mathrm{CD}$ is a gluten-induced immune-mediated inflammatory disorder of the small intestine caused by an intolerance to dietary gluten. CD is limited to genetically predisposed individuals who carry HLA-DQ2.5, HLA-DQ8, HLA-DQ2.2 and/or rarely HLADQ7 haplotypes located on the short arm of chromosome $6^{60-64}$ The results of several Genome-wide association studies (GWAS), for example, most recently in a prospective study of 6010 children that carried HLA genotypes associated with increased risk of type-1 diabetes and $\mathrm{CD}$, have also reported the role of non-HLA genes in CD presentation. ${ }^{65}$ Other immunologic and environmental factors are also involved in the development of CD. ${ }^{66}$ For instance, Caminero et $\mathrm{al}^{57}$ demonstrated that opportunistic bacterial pathogens (such as $\mathrm{P}$. aeruginosa) in duodenal biopsies from active CD patients could increase mucosal injury caused by immunogenic gluten-derived peptides in a mouse model through protease production and proteaseactivated receptor-2 (PAR-2) signaling. ${ }^{57}$

In general, the most immunogenic wheat gluten peptides in CD are derived from $\alpha$-gliadins (Figure 2). ${ }^{47,67}$ Some repetitive sequences include two or more overlapping immunodominant epitopes that bind to HLA-DQ2.5, while others include single copies of epitopes that bind HLA-DQ8 or HLA-DQ2.2 and stimulate effector memory CD4+ T cells. ${ }^{68}$ According to standardized nomenclature, the most immunogenic fragment of $\alpha$-gliadin for patients positive for HLA-DQ2.5 encompasses multiple copies of the overlapping DQ2.5-glia- $\alpha 1 \mathrm{a}$, DQ2.5-glia- $\alpha 1 \mathrm{~b}$, and DQ2.5-glia- $\alpha 2$ epitopes. ${ }^{68,69}$ Wheat $\alpha$-gliadin also includes the subdominant DQ2.5-glia- $\alpha 3$ epitope, DQ8-glia- $\alpha 1$, DQ2.2-glia- $\alpha 1$ and the DQ2.2-glia- $\alpha 2$ epitopes, which are relevant in patients who are positive for HLA-DQ8, and/or

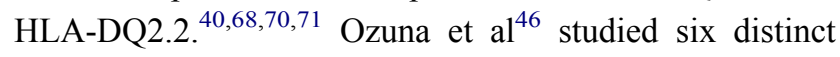
types of $\alpha$-gliadins in diploid and polyploid wheats through next-generation sequencing and Sanger sequencing. They found that $\alpha$-gliadin sequences differed significantly in their frequencies and in the existence and abundance of CD immunogenic peptides. Their findings may help reduce the risk of CD incidence by the breeding/ selection of wheat with low stimulatory properties. ${ }^{46}$ Wheat $\omega$-gliadin, however, includes two overlapping immunodominant epitopes, DQ2.5-glia- $\omega 1$ and DQ2.5-glia- $\omega 2$, that resemble DQ2.5-glia- $\alpha 1 \mathrm{a}$ and DQ2.5-glia- $\alpha 2$, but stimulate a distinct population of CD4+ T cells and appear to be responsible for many crossreactive $\mathrm{CD} 4+\mathrm{T}$ cells activated by wheat, barley and rye. $^{47,72}$

Gluten proteins are highly resistant to human digestive proteases (due to their high content of proline) and do not fully degrade during gastric and pancreatic digestion. ${ }^{34,69}$ Two peptides that have attracted most attention and remain intact in the digestive process are the 33-mer (p55-87) and the 25-mer (p31-55) located in the $\alpha$ gliadins encoded by the Gli-D2 locus on chromosome $6 \mathrm{D} .^{73,74}$ Of these two peptides, the 33 -mer is the most digestion-resistant peptide with high immunogenic properties (contains DQ2.5-glia- $\alpha 1 \mathrm{a}$, DQ2.5-glia- $\alpha 1 \mathrm{~b}$, and DQ2.5-glia- $\alpha 2$ epitopes). ${ }^{75,76}$ During or after absorption of partially digested gliadin peptides into the lamina propria, specific glutamine residues of the 33-mer peptide are susceptible to $\mathrm{pH}$-dependent transamidation (covalent cross-linking to free amines, for example, lysine residues 


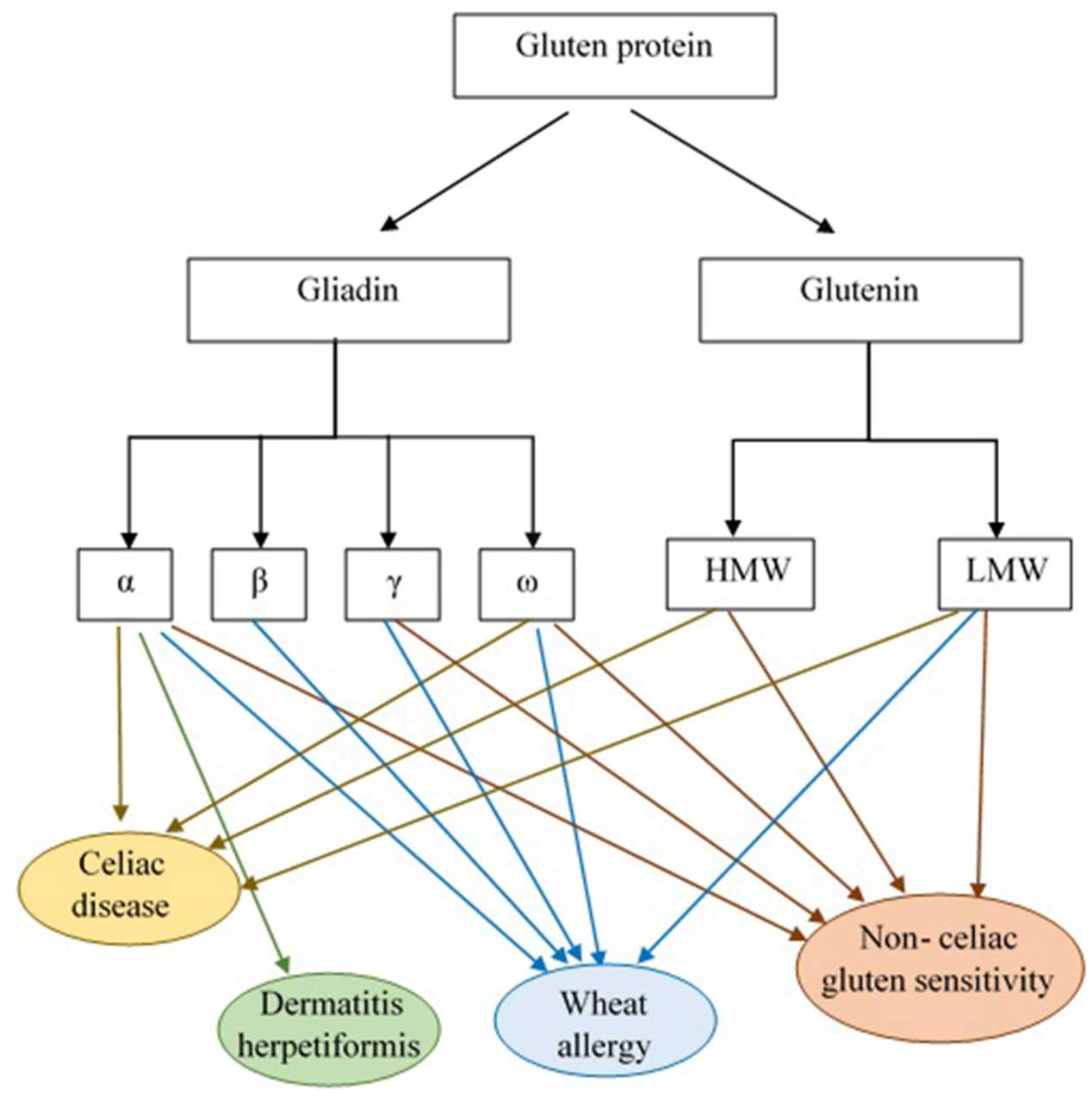

Figure 2 Gluten protein components and the role of its subgroups in GRDs pathogenesis. According to the results of studies $\alpha$ and $\gamma$-gliadins and glutenin are considered to be CD pathogenic responses eliciting factors. The $\alpha$-gliadin fraction is also reported as DH immunological response triggering agent. Allergic reactivity to the $\alpha$-/ $\beta$-, $\gamma$ - and $\omega$ gliadin fractions and LMW-GS was observed in WA patients. Moreover, patients with NCGS revealed high levels of lgG antibodies against $\alpha$-, $\gamma$ - and $\omega$-gliadin and glutenin. Abbreviations: HMW, high molecular weight; LMW, low molecular weight.

in other proteins) or direct deamidation to glutamate through the action of extracellular tissue transglutaminase (tTG) expressed in inflamed host tissues. ${ }^{77-79}$ Transamidation abolishes the immunotoxicity of gluten epitopes, ${ }^{80}$ but direct deamidation enhances their affinity for HLA-DQ2.5 and is essential for their immunogenicity. ${ }^{80-82}$ tTG-affected peptides are efficiently presented to CD4+ T-cells by the HLA-DQ molecules implicated in CD susceptibility. This results in glutenspecific CD4+ T cell activation with the secretion of proinflammatory cytokines like interleukin-2 (IL-2), IL-21 and interferon-gamma (IFN $\gamma$ ), antigen-non-specific activation of local cytotoxic CD8+ T cells, ${ }^{83,84}$ and enterocyte injury and apoptosis, which ultimately contribute to the characteristic mucosal lesions and local inflammation associated with active CD. Gluten-stimulated CD4+
$\mathrm{T}$ cells also provide help for gliadin and tTG-specific B cells, and support antibody production by specific plasma cells. $^{84-87}$ Glutenin peptides are also implicated in T-cell responses. ${ }^{87}$ In contrast, the in vitro effects of the $\alpha$-gliadin 25-mer peptide include induction of IL-15 production from enterocytes and dendritic cells, and innate immune activation. ${ }^{88}$ IL-15 promotes induction of inflammatory Th1 cell responses and also activation of cytotoxic CD8+ IELs leads to the development of the intestinal lesions. $^{89,90}$ The contribution of IL-15 to mucosal injury facilitated by induction of CD4+ T-cell immunity to gluten has been supported by a recently reported HLA-DQ8expressing mouse model with overproduction of IL-15 in the gut epithelium and lamina propria, which develop gluten-dependent small intestinal villous atrophy mimicking human $\mathrm{CD} .^{91}$ 
Tye-din et $\mathrm{al}^{47}$ in their follow-up study on HLA-DQ2.5 + CD patients screened for T cell-stimulatory gluten peptides in blood following a brief oral challenge with wheat, barley, and rye. They showed that $\alpha$-gliadin 33-mer epitopes (DQ2- $\alpha-\mathrm{I}$ and DQ2- $\alpha-\mathrm{II})$ are immunodominant only after the wheat challenge, while $\omega$-gliadin/C-hordeinderived sequences encompassing DQ2- $\omega 1 / \omega 2$ were the dominant $\mathrm{T}$ cell-stimulatory peptides in response to consumption of any of these cereals. Hence, they considered $\omega$-gliadin/C-hordein-derived peptides as common T cellstimulatory peptides in HLA-DQ2.5-associated CD patients. ${ }^{47}$

Nutrient malabsorption results from mucosal injury marked by villous blunting, crypt hyperplasia, increased intraepithelial lymphocytes (IELs) infiltrate, and immunemediated enteropathy along with. ${ }^{92}$ Gluten-induced systemic inflammation in $\mathrm{CD}$ is characterized by the presence of intestinal and/or extra-intestinal manifestations or it can even be completely asymptomatic. ${ }^{59}$

Dermatitis herpetiformis (DH) is one of the extraintestinal presentations of $\mathrm{CD}$ that is accompanied by the development of papulovesicular pruritic skin rash on the extensor aspects of the limbs, sacral region, and buttocks. ${ }^{59,93}$ As reported in previous studies, topical or intradermal use of gluten protein does not lead to DH formation and the incidence of this disorder is related to intestinal contact with gluten. ${ }^{93}$ In fact, anti-tTG antibodies, made in response to gluten consumption, interact with the epidermal transglutaminase (ETG) enzyme and cause DH symptoms. ${ }^{59}$ Allardyce and Shearman ${ }^{94}$ in their study reported that cellular immune reactivity to the $\alpha$ gliadin fraction was also observed in DH patients. Moreover, Huff et $\mathrm{al}^{95}$ reported high levels of alphagliadin-specific antibodies in patients with $\mathrm{DH}$ (Figure 2). Therefore, more studies are required to evaluate the exact pathogenic fractions of gluten in $\mathrm{DH}$.

\section{Wheat Allergy (WA)}

Wheat is one of the most common allergens and wheat allergy (WA) results from immunological adverse reactions to wheat ingredients, including water-soluble (albumin and globulin) and insoluble (glutenin and gliadin) proteins. ${ }^{56,96-99}$ In fact, skin contact, inhalation or ingestion of wheat can lead to the occurrence of these allergic reactions. ${ }^{97}$ Wheat-dependent exercise-induced anaphylaxis (WDEIA), where symptoms result from the ingestion of wheat in combination with physical exercise, and baker's asthma, that caused by inhalation of wheat flour, are classified as two commonly WA. ${ }^{97,100}$ With a higher rate of reports in pediatrics, the prevalence of this disorder is reported to be between $0.5 \%$ and $1 \%$ in the world. ${ }^{59,98}$

Scientific reports have considered wheat $\omega-5$ gliadin (fast $\omega$-gliadin, Tri a 19), encoded by the Gli-1 locus on chromosome 1B, as the major allergen part of gluten protein for various types of WA especially WDEIA (also known as $\omega 5$-gliadin allergy) (Figure 2). ${ }^{101,102}$ Morita et $\mathrm{al}^{103}$ reported that fast $\omega$-gliadin is the main allergen for Japanese WDEIA patients. Moreover, results of the study conducted by Palosuo et al ${ }^{104}$ showed that $\gamma$ 70 and $\gamma-35$ secalins in rye and $\gamma-3$ hordein in barley that have structural homology and cross-reactivity with $\omega-5$ gliadin could bind to IgE antibodies and elicit symptoms in WDEIA patients. Since WDEIA diagnosis is significantly delayed, Kennard et a ${ }^{105}$ recommended the use of $\omega-5$ gliadin-specific IgE testing for patients with unexplained anaphylaxis. ${ }^{104}$ Moreover, according to Sandiford et al, ${ }^{106} \alpha$ - and fast $\omega$-gliadin are also associated with baker's asthma allergic reactions (Figure 2). ${ }^{105}$ Positive IgE responses to several other wheat grain proteins, such as $\alpha / \beta$ - (Tri a 21), $\gamma$-gliadins, low molecular weight (LMW) glutenin, and $\alpha$-amylase /trypsin inhibitors (ATIs) are also reported (Figure 2). ${ }^{98}$ For instance, Baar et al, ${ }^{107}$ using a molecular discovery approach, found that Tri a 36, which belongs to the LMW-GSs (GluB3-23), is a wheat food allergen with IgE-reactive sequences. ${ }^{56,107}$

Following contact with allergens, secretion of IL- 25 or IL-33 from epithelial cells leads to T helper type 2 (Th2) cell response activation and subsequently $\operatorname{IgE}$ antibodies production by B-cells. ${ }^{108}$ This secreted IgE antibody bound to FceRI receptor on mast cells and basophils as well as to specific epitopes in wheat allergens resulting in the release of inflammatory chemical mediators such as histamine and platelet activator factor (PAF) (Figure 3). ${ }^{25}$ As a result, allergic responses (such as itching, eczema, rhinitis, nausea) can be life-threatening and cause anaphylactic shock in some cases. ${ }^{25}$

\section{Non-Celiac Gluten Sensitivity (NCGS)}

Non-celiac gluten sensitivity (NCGS) or gluten sensitivity, which remains ill-defined, is a condition resulting from reactions to gluten-containing grains without IgEmediated or T-cell-mediated responses. ${ }^{59,109-111}$ Recent studies found that different non-gluten components of wheat flour such as ATIs, Fermentable Oligosaccharides, Disaccharides, Monosaccharides, and Polyols 


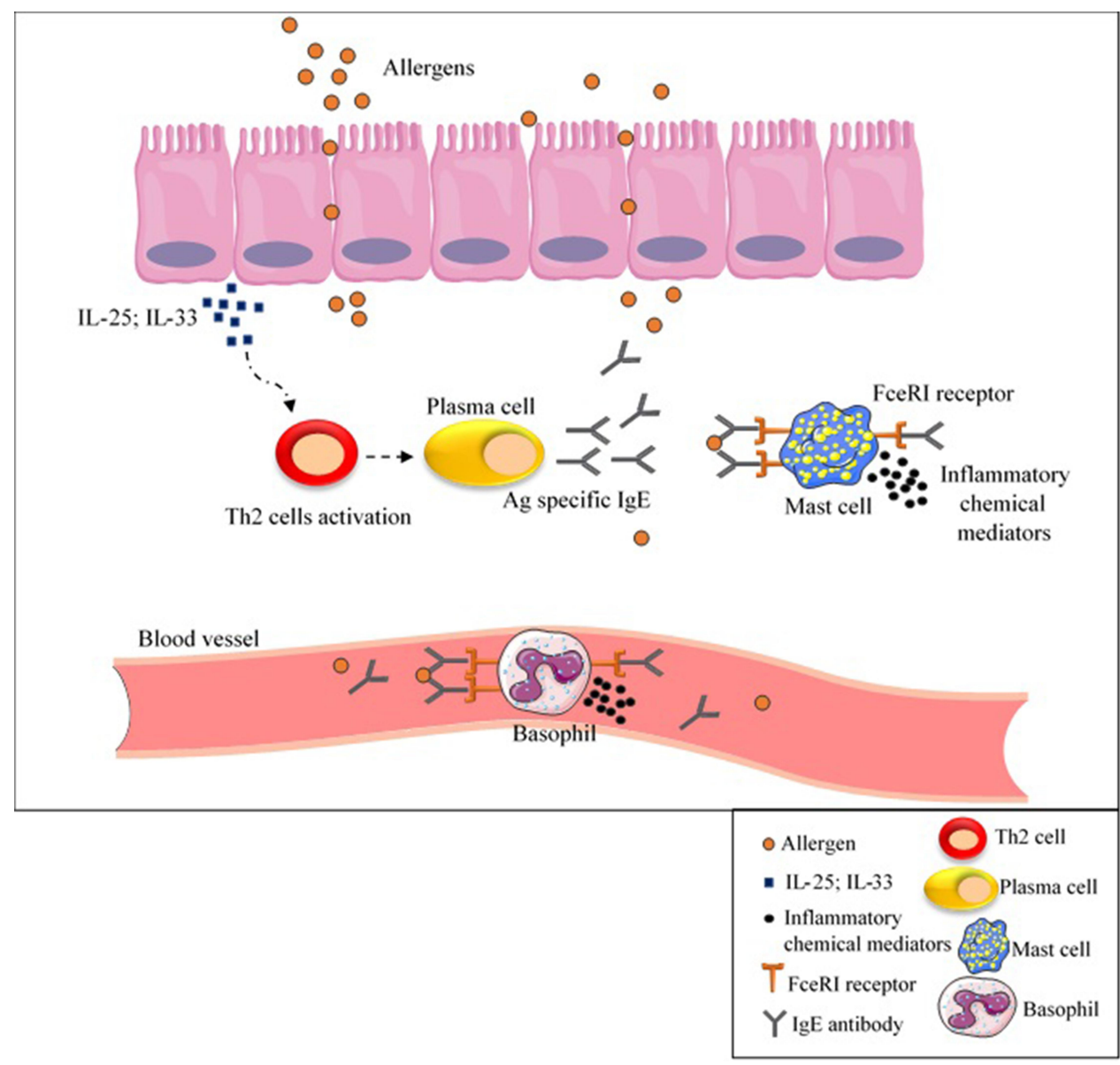

Figure 3 lgE- mediated wheat allergy. As a result of contact with allergens, IL-25 or IL-33 are secreted from epithelial cells, cause Th2 cell response activation and subsequently IgE antibodies production by B-cells. Inflammatory chemical mediators are released as a result of IgE antibody binding to FceRI receptor on mast cells and basophils as well as to specific epitopes in wheat allergens, causing allergic reactions.

Abbreviations: Ag, antigen; IgE, immunoglobulin E; IL, interleukin; Th2, T helper type 2.

(FODMAPs) causing irritable bowel syndrome might also contribute to NCGS. ${ }^{59,112}$

The precise pathogenesis of NCGS is still obscure; nevertheless, it has been reported that activation of the innate immune system could have a role in some patients with this condition. ${ }^{113}$ In this regard, a decrease in $\mathrm{T}$ helper cell numbers and a reduction in regulatory $\mathrm{T}$ cell clones expansion and their cytokines production have been reported in mucosal biopsy specimens of NCGS patients. ${ }^{114,115}$ Some early studies reported that HLA-DQ2 and/or -DQ8 genotypes could be overexpressed in NCGS, although these molecules are found in only around $50 \%$ of NCGS patients, which is not dissimilar to the general population. ${ }^{56}$ NCGS is a widespread disorder with an estimated prevalence of $0.5 \%$ to $13 \%$, which is more frequent in adult females. ${ }^{116}$

Given the lack of a definitive test to diagnose NCGS, which in some cases may be confused with CD or WA, several research studies focus on finding NCGS-specific serum biomarkers. ${ }^{117,118}$ Tye-Din et $\mathrm{al}^{119}$ in their study on $\mathrm{CD}$ and self-reported gluten sensitive (SR-GS) patients found that gluten challenge significantly increased IL-2, IL-8 and IL-10 serum levels in CD but not SR-GS patients (both groups had completely eliminated gluten from their diet before participating in the challenge). They concluded that cytokine assessment after acute gluten challenge could be used for distinguishing CD from SR-GS. ${ }^{119}$ Uhde et al120 also reported a significant increase in anti-gliadin IgG1 and $\operatorname{IgG} 3$, and $\mathrm{IgG} 2$ and IgG4 subclasses in CD and NCGS patients, respectively. There was also a correlation between the IgG4 and IgG3 antibodies and serum concentration of Fatty acid-binding protein 2 (FABP2), which is an intestinal cell damage marker. They proposed that these components might be additional biomarkers to differentiate CD and NCGS. ${ }^{120}$ The only presented case report by Vojdani and Perlmutter of a patient with NCGS and 
autoimmunity revealed high levels of IgG antibodies against $\alpha$-gliadin 33 and 17 mer, $\gamma$ - and $\omega$-gliadin and glutenin (Figure 2). ${ }^{121}$

The chronic symptoms ascribed to NCGS are similar to those of untreated $\mathrm{CD}$ with a wide range of intestinal and extra-intestinal presentation as highlighted in Salerno expert criteria. ${ }^{4,117}$ In contrast, the double-blind shamcontrolled gluten challenge that is low in FODMAPs does not generally induce measurable symptoms in patients self-reporting NCGS, whereas patients with treated $\mathrm{CD}$ typically experience acute upper gastrointestinal symptoms and show elevations in serum IL-2 within 2 hours. ${ }^{122,123}$

\section{Wheat Genome Editing}

Currently removing gluten from the diet is the only remedy to improve the symptoms of people prone to GRDs. ${ }^{124}$ However, the addition of gluten to numerous food products and the high cost of gluten-free foodstuffs have made it difficult to strictly adherence to this diet. $^{15,27,125}$ As a result, several genetic studies have focused on breeding wheat with low immunological properties and preserved baking quality through biotechnological approaches. Numerous scientists believe that gene editing would be a definitive solution for GRDs; however, due to the variety of causal agents, it is not so easy to solve them all in this way ${ }^{126-128}$ Biotechnological approaches are used for precise and organized modifying of specific genomic sequences through their different functions such as gene replacement, targeted gene knock-out and knockin, etc. ${ }^{129,130}$ Vasil et al ${ }^{131}$ were the first group to successfully produce transgenic wheat plants in 1992 through the Bar gene transferring by biolistic particle bombardment method. The Bar gene encodes phosphinothricin acetyltransferase (PAT) enzyme, which is the cause of herbicide tolerance of plants. ${ }^{131}$ RNA interference (RNAi) and CRISPR/Cas9 are the two recent biotechnology methods used in this regard. ${ }^{126}$

RNA interference (RNAi) is a post-transcriptional process present in almost all eukaryotic organisms and regulates the expression of protein-coding genes in a sequence-specific manner, which is capable of engineering novel phenotypes. ${ }^{132,133}$ In fact, RNAi suppresses protein synthesis by using short double-stranded RNA (dsRNA) complementary to target mRNA and degrading that (silencing of the gene). ${ }^{134}$ It has been shown that this method is very efficient in regulating gene expression in numerous plant systems. ${ }^{135}$ Gil-Humanes et al ${ }^{136}$ used this method to produce breads with up to $97 \%$ lower gliadin content (near gliadin-free). The results of their study showed that these reduced-gliadin breads had lower immunotoxicity compared to wild types, while physically no difference was observed between them. Additionally, the removal of gliadin leads to an increase in the number of lysine amino acids (due to the increase in glutenin content which contains more lysine residues) that increases the nutritional value of these breads. ${ }^{136}$ Altenbach et $\mathrm{al}^{137}$ suppressed the expression of $\omega-5$ gliadins (as an important food allergen) in the US wheat cv Butte 86 using RNA interference technique. The results of their study showed that removing $\omega-5$ gliadins from wheat did not affect flour functionality and had no effect on the expression of other grain proteins. Conversely, the removal of this part improved the dough properties and increased protein stability, indicates the negative role of $\omega-5$ gliadins in flour quality. ${ }^{137}$ In comparison, Altenbach et al ${ }^{138}$ in their recent study used the same method to silence a subset of alphagliadin genes (containing CD epitopes) of wheat flour from the US spring wheat cultivar Butte 86. Analysing reactivities of $\operatorname{IgG}$ and $\operatorname{IgA}$ antibodies from patients with CD showed a significantly reduced immunoreactivity of the flour. However, their results showed a decrease in functional properties and dough strength in the transgenic lines. They proposed that the simultaneous removal of alpha and omega gliadins from wheat could be a more efficient approach in this regard. ${ }^{138}$ In a comprehensive study, Barro et $\mathrm{al}^{139}$ reported the effectiveness of seven RNAi containing plasmids with the ability to target $\alpha-, \gamma-$, $\omega$-gliadins, and LMW glutenin subunits in breeding nontoxic wheat variants without any CD epitopes. ${ }^{139}$ Targeted gene knockdown by RNAi is a fast, low-cost and easy-toperform method, however, while effective, it provides only transitory inhibition of gene function and may also have unpredictable effects on target genes leads to limited use of this method. ${ }^{5,140}$

There are some editing genome tools based on the effect of site-specific DNA-binding domain and the use of engineered nucleases, that can identify and edit a particular DNA sequence, including zinc-finger nucleases (ZFNs) and transcription activator-like effector nucleases (TALENs). ${ }^{5}$ The clustered regularly interspersed short palindromic repeats (CRISPR)/Cas system, especially CRISPR-associated protein 9 (CRISPR/Cas9), is a widely used prokaryotic nuclease-based target gene precise editing tool, which known as an effective alternative to ZFNs and TALENs. ${ }^{5,141,142}$ CRISPR/Cas9, 
identified as the most popular genetic engineering technique, causes genome modifications by delivering to plant cells and expressing there. ${ }^{129,142,143}$ In this method, the single guide RNA (sgRNA) directs the caspase to the target DNA sites and helps breeding low immunogenic epitopes containing plants with greater specificity. ${ }^{144}$ The first successful use of CRISPR-Cas9 system was to knock out TaMLO gene (Mildew-resistance locus $\mathrm{O}$ ) in wheat protoplasts which leads to improved disease resistance that brings the importance of the CRISPR/Cas9 system to promote important traits. ${ }^{145}$ Sánchez-León et al, ${ }^{146}$ using two single guide RNAs (sgAlpha-1 and sgAlpha-2) targeted coding sequence for $\alpha$-gliadin genes, show that CRISPR/Cas9 technology could be used for providing wheat lines with reduced immunoreactivity. ${ }^{145}$ Jouanin et al ${ }^{147}$ in their pilot study reported the efficacy of CRISPR/Cas9, using six sgRNA sequences, in mutating $\alpha$ - and $\gamma$-gliadin gene copies and preventing them from triggering the human immune system. ${ }^{147}$

The Court of Justice of the European Union (CJEU) in July 2018 considered any crop with altered genetic material caused by new plant breeding techniques (unnatural changes) as genetically modified organisms (GMOs), which are subjects within the scope of EU law and can be used. This judgment, although supported by some, has also provoked criticism, which led to the formation of the new European Commission that may result in the EU's GMO legislation change. ${ }^{148}$

\section{Conclusion}

As lifelong adherence to a gluten-free diet remains a challenge for GRDs patients, it seems that increasing attention to the immunogenetic properties of gluten constituents is an essential element in improving the condition of patients. In this regard, technologies have been designed that can reduce the immunogenicity properties of gluten by promising a genomic editing approach. Although these techniques mostly work precisely on the target gene, it is important to note that changes in the expression of one gene how affect the expression of other genes? It can be said that one of the reasons for not including these manipulated products in patients' diets is the lack of a clear answer to this question. Therefore, it is suggested that future studies in this regard consider all genomeediting results (either genetic or metabolic changes) to ensure the created product compatibility with food safety conditions.

\section{Abbreviations}

ATIs, Alpha-amylase/Trypsin Inhibitors; CD, Celiac Disease; CRISPR, Clustered Regularly Interspersed Short Palindromic Repeats; DH, Dermatitis herpetiformis; ETG, Epidermal Transglutaminase; FABP2, Fatty Acid-Binding Protein 2; FODMAPs, Fermentable Oligosaccharides, Disaccharides, Monosaccharides, and Polyols; g, Gram; GWASs, Genome-Wide Association Studies; HMW, High Molecular Weight; IELs, Intraepithelial Lymphocytes; IgE, Immunoglobulin E; IL, Interleukin; $\mathrm{kDa}$, Kilodalton; LMW, Low Molecular Weight; NCGS, Non-Celiac Gluten Sensitivity; P, Proline; PAF, Platelet Activator Factor; PAT, Phosphinothricin Acetyltransferase; PI, Isoelectric Point; Q, Qlutamine; RNAi, RNA interference; sgRNA, single guide RNA; SR-GS, Self-Reported Gluten Sensitive; TALENs, Transcription Activator-Like Effectors Nucleases; Th2, T helper type 2; tTG, Tissue Transglutaminase; WA, Wheat Allergy; WDEIA, WheatDependent Exercise-Induced Anaphylaxis; ZFNs, ZincFinger Nucleases.

\section{Author Contributions}

All authors made a significant contribution to the work reported in all of the following areas: took part in drafting, revising or critically reviewing the article; gave final approval of the version to be published; have agreed on the journal to which the article has been submitted; and agree to be accountable for all aspects of the work.

\section{Funding}

There is no funding to report.

\section{Disclosure}

Dr Robert P Anderson reports personal fees from consultancies for GSK (Wilmington, DE, USA; since 2019), Allero Therapeutics BV (Rotterdam, Netherlands; since 2020), Takeda Pharmaceutical Company Ltd/Millennium Pharmaceuticals (Cambridge MA USA; since 2019), Kanyos Bio Inc (Cambridge MA USA; since 2019), Atheneum Partners GmbH (Berlin, Germany; since 2019), being an ImmusanT Inc, CSO, employee until September 2019, principal and founder of Specific Pharma Consulting, and founder and part-owner of Novoviah Pharmaceuticals Pty Ltd, outside the submitted work; in addition, Dr Robert $\mathrm{P}$ Anderson has multiple patents licensed to ImmusanT (patents lodged from 2009 to 2019 relating diagnosis, and treatment of coeliac 
disease) and BTG International (patents lodged from 2009 to 2019 relating diagnosis, treatment, and modification of gluten for coeliac disease). The authors declare that they have no other potential conflicts of interest for this work.

\section{References}

1. Shiferaw B, Smale M, Braun H-J, et al. Crops that feed the world 10. Past successes and future challenges to the role played by wheat in global food security. Food Secur. 2013;5(3):291-317. doi:10.1007/s12571-013-0263-y

2. Utebayev M, Dashkevich S, Bome N, et al. Genetic diversity of gliadin-coding alleles in bread wheat (Triticum aestivum L.) from Northern Kazakhstan. PeerJ. 2019;7:e7082. doi:10.7717/ peerj. 7082

3. Bell G. The History of Wheat Cultivation. Wheat Breeding. Springer; 1987:31-49.

4. Wang D, Li F, Cao S, Zhang K. Genomic and functional genomics analyses of gluten proteins and prospect for simultaneous improvement of end-use and health-related traits in wheat. Theor Appl Genet. 2020;133(5):1521-1539. doi:10.1007/s00122-02003557-5

5. Liaqat N, Liaqat A, Ali M, et al. Chapter 24 - Wheat genomics and genome editing. In: Ozturk M, Gul A, editors. Climate Change and Food Security with Emphasis on Wheat. Academic Press; 2020:331-346.

6. Rostami K, Malekzadeh R, Shahbazkhani B, et al. Coeliac disease in Middle Eastern countries: a challenge for the evolutionary history of this complex disorder? Dig Liver Dis. 2004;36 (10):694-697. doi:10.1016/j.dld.2004.05.010

7. Huo N, Zhu T, Altenbach S, et al. Dynamic evolution of $\alpha$-gliadin prolamin gene family in homeologous genomes of hexaploid wheat. Sci Rep. 2018;8(1):5181. doi:10.1038/s41598-018-23 570-5

8. Metakovsky E, Melnik V, Rodriguez-Quijano M, et al. A catalog of gliadin alleles: polymorphism of 20th-century common wheat germplasm. Crop J. 2018;6(6):628-641. doi:10.1016/j. cj.2018.02.003

9. Altenbach SB, Kothari KM, Lieu D. Environmental conditions during wheat grain development alter temporal regulation of major gluten protein genes. Cereal Chem J. 2002;79 (2):279-285. doi:10.1094/CCHEM.2002.79.2.279

10. Shewry PR, Hey SJ. The contribution of wheat to human diet and health. Food Energy Secur. 2015;4(3):178-202. doi:10.1002/ fes3.64

11. Shewry P. What is gluten-why is it special? Front Nutr. 2019;6:101. doi:10.3389/fnut.2019.00101

12. Islam $\mathrm{S}, \mathrm{Yu} \mathrm{Z}$, She $\mathrm{M}$, et al. Wheat gluten protein and its impacts on wheat processing quality. Front Agric Sci Eng. 2019;6 (3):279-287. doi:10.15302/J-FASE-2019267

13. Kumar P, Yadava R, Gollen B, et al. Nutritional contents and medicinal properties of wheat: a review. Life Sci Med Res. 2011;22:1-10.

14. Wieser H. Chemistry of gluten proteins. Food Microbiol. 2007;24:115-119. doi:10.1016/j.fm.2006.07.004

15. Jouanin A, Boyd L, Visser RGF, Smulders MJM. Development of wheat with hypoimmunogenic gluten obstructed by the gene editing policy in Europe. Front Plant Sci. 2018;9:1523. doi:10.3389/fpls.2018.01523

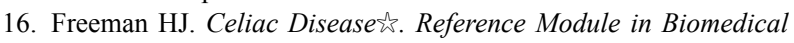
Sciences. Elsevier; 2017.

17. Pasha I, Saeed F, Sultan MT, et al. Wheat allergy and intolerance; recent updates and perspectives. Crit Rev Food Sci Nutr. 2016;56 (1):13-24. doi:10.1080/10408398.2012.659818
18. Barak S, Mudgil D, Khatkar BS. Influence of gliadin and glutenin fractions on rheological, pasting, and textural properties of dough. Int J Food Prop. 2014;17(7):1428-1438. doi:10.1080/ 10942912.2012.717154

19. Biesiekierski JR. What is gluten? J Gastroenterol Hepatol. 2017;32(S1):78-81. doi:10.1111/jgh.13703

20. Kajendran K, Chandrasekharan NV, Hettiarachchi CM, Sulochana Wijesundera WS. Molecular characterization and expression of $\alpha$ gliadin genes from wheat cultivar Dacke in Bg 250 rice variety. GM Crops Food. 2019;10(2):102-114. doi:10.1080/ 21645698.2019.1622990

21. Tian N, Leffler DA, Kelly CP, et al. Despite sequence homologies to gluten, salivary proline-rich proteins do not elicit immune responses central to the pathogenesis of celiac disease. Am J Physiol Gastrointest Liver Physiol. 2015;309(11):G910-G917. doi:10.1152/ajpgi.00157.2015

22. Kumar J, Kumar M, Pandey R, Chauhan NS. Physiopathology and management of gluten-induced celiac disease. J Food Sci. 2017;82(2):270-277. doi:10.1111/1750-3841.13612

23. Phiarais BPN, Arendt EK. 15 - Malting and brewing with glutenfree cereals. In: Arendt EK, Dal Bello F, editors. Gluten-Free Cereal Products and Beverages. San Diego: Academic Press; 2008:347-372.

24. Sharma N, Bhatia S, Chunduri V, et al. Pathogenesis of celiac disease and other gluten related disorders in wheat and strategies for mitigating them. Front Nutr. 2020;7.

25. Cabanillas B. Gluten-related disorders: celiac disease, wheat allergy, and nonceliac gluten sensitivity. Crit Rev Food Sci Nutr. 2020;60(15):2606-2621. doi:10.1080/10408398.2019.1651689

26. Lammers KM, Herrera MG, Dodero VI. Translational chemistry meets gluten-related disorders. ChemistryOpen. 2018;7 (3):217-232. doi:10.1002/open.201700197

27. Rostami Nejad M, Karkhane M, Marzban A, et al. Gluten related disorders. Gastroenterol Hepatol Bed Bench. 2012;5(Suppl 1): $\mathrm{S} 1-\mathrm{S} 7$.

28. Czerwińska K, Czerwiński G, Poniewierka E, et al. Spectrum of gluten-related disorders: celiac disease, wheat allergy, baker's asthma and non-celiac gluten sensitivity. World Sci News. 2018;100:154-164.

29. Tanner G, Juhász A, Florides CG, et al. Preparation and characterization of avenin-enriched oat protein by chill precipitation for feeding trials in celiac disease. Front Nutr. 2019;6(162). doi:10.3389/fnut.2019.00162.

30. Spector Cohen I, Day AS, Shaoul R. To be oats or not to be? An update on the ongoing debate on oats for patients with celiac disease. Front Pediatr. 2019;7:384. doi:10.3389/fped.2019. 00384

31. Hollén E, Holmgren Peterson K, Sundqvist T, et al. Coeliac children on a gluten-free diet with or without oats display equal anti-avenin antibody titres. Scand J Gastroenterol. 2006;41 (1):42-47. doi:10.1080/00365520510023945

32. Haboubi NY, Taylor S, Jones S. Coeliac disease and oats: a systematic review. Postgrad Med J. 2006;82(972):672-678. doi:10.1136/pgmj.2006.045443

33. Hardy MY, Tye-Din JA, Stewart JA, et al. Ingestion of oats and barley in patients with celiac disease mobilizes cross-reactive $\mathrm{T}$ cells activated by avenin peptides and immuno-dominant hordein peptides. J Autoimmun. 2015;56:56-65.

34. Balakireva AV, Zamyatnin AA. Properties of gluten intolerance: gluten structure, evolution, pathogenicity and detoxification capabilities. Nutrients. 2016;8(10):644. doi:10.3390/ nu8100644

35. Békés F, Gianibelli MC, Wrigley CW. The gluten proteins of the wheat grain in relation to flour quality. In: Wrigley $\mathrm{C}$, Corke $\mathrm{H}$, Seetharaman K, Faubion J, editors. Encyclopedia of Food Grains (Second Edition). Oxford: Academic Press; 2016:375-383. 
36. Shewry PR, Halford NG, Lafiandra D. Genetics of wheat gluten proteins. In: Hall JC, Dunlap JC, Friedmann T, editors. Advances in Genetics. Vol. 49. Academic Press; 2003:111-184.

37. Zaefizadeh M, Jamaati-e-Somarin S, Ojaghi J, et al. Genetic diversity for gliadin patterns of durum wheat landraces in the Northwest of Iran and Azerbaijan. Pesquisa Agropecuária Brasileira. 2010;45(12):1425-1432. doi:10.1590/S0100204X2010001200013

38. Wang D-W, Li D, Wang J, et al. Genome-wide analysis of complex wheat gliadins, the dominant carriers of celiac disease epitopes. Sci Rep. 2017;7(1):44609. doi:10.1038/srep44609

39. Žilić S. Wheat Gluten: Composition and Health Effects. Nova Science Publishers, lnc. 2013:71-86.

40. Dubois B, Bertin P, Mingeot D. Molecular diversity of $\alpha$-gliadin expressed genes in genetically contrasted spelt (Triticum aestivum ssp. spelta) accessions and comparison with bread wheat (T. aestivum ssp. aestivum) and related diploid Triticum and Aegilops species. Mol Breed. 2016;36(11):152. doi:10.1007/ s11032-016-0569-5

41. Gianibelli M, Larroque O, Macritchie F, Wrigley C. Biochemical, genetic, and molecular characterization of wheat endosperm proteins. Cereal Chem Rev. 2001;78(6):635-646. doi:10.1094/ CCHEM.2001.78.6.635

42. Li Y, Xin R, Zhang D, Li S. Molecular characterization of $\alpha$ gliadin genes from common wheat cultivar Zhengmai 004 and their role in quality and celiac disease. Crop J. 2014;2(1):10-21. doi:10.1016/j.cj.2013.11.003

43. Harberd N, Bartels D, Thompson R. Analysis of the gliadin multigene loci in bread wheat using nullisomic-tetrasomic lines. Mol Gen Genet. 1985;198(2):234-242. doi:10.1007/BF00383001

44. Anderson $\mathrm{O}$, Litts J, Greene F. The $\alpha$-gliadin gene family. I. Characterization of ten new wheat $\alpha$-gliadin genomic clones, evidence for limited sequence conservation of flanking DNA, and southern analysis of the gene family. Theor Appl Genet. 1997;95 (1-2):50-58. doi:10.1007/s001220050531

45. Okita T, Cheesbrough V, Reeves CD. Evolution and heterogeneity of the alpha-/beta-type and gamma-type gliadin DNA sequences. $J$ Biol Chem. 1985;260(13):8203-8213. doi:10.1016/S00219258(17)39582-0

46. Ozuna CV, Iehisa JC, Giménez MJ, et al. Diversification of the celiac disease $\alpha$-gliadin complex in wheat: a 33 -mer peptide with six overlapping epitopes, evolved following polyploidization. Plant J. 2015;82(5):794-805. doi:10.1111/tpj.12851

47. Tye-Din JA, Stewart JA, Dromey JA, et al. Comprehensive, quantitative mapping of $\mathrm{T}$ cell epitopes in gluten in celiac disease. Sci Transl Med. 2010;2(41):41ra51. doi:10.1126/ scitranslmed.3001012

48. Rasheed F, Plivelic TS, Kuktaite R, et al. Unraveling the structural puzzle of the giant glutenin polymer-an interplay between protein polymerization, nanomorphology, and functional properties in bioplastic films. ACS Omega. 2018;3(5):5584-5592. doi:10.1021/acsomega.7b02081

49. Fu BX, Sapirstein HD. Procedure for isolating monomeric proteins and polymeric glutenin of wheat flour. Cereal Chem J. 1996;73(1):143-152.

50. Dangi P, Khatkar BS. Extraction and purification of low molecular weight glutenin subunits using size exclusion chromatography. J Food Sci Technol. 2019;56(2):951-956. doi:10.1007/s13197-018-03560-1

51. Wang Y, Zhen S, Luo N, et al. Low molecular weight glutenin subunit gene Glu-B3h confers superior dough strength and breadmaking quality in wheat (Triticum aestivum L.). Sci Rep. 2016;6 (1):27182. doi:10.1038/srep27182

52. Liu L, Ikeda TM, Branlard G, et al. Comparison of low molecular weight glutenin subunits identified by SDS-PAGE, 2-DE, MALDI-TOF-MS and PCR in common wheat. BMC Plant Biol. 2010;10:124. doi:10.1186/1471-2229-10-124
53. Wang $\mathrm{Z}$, Huang $\mathrm{L}, \mathrm{Wu} \mathrm{B}$, et al. Characterization of an integrated active Glu-1Ay allele in common wheat from wild emmer and its potential role in flour improvement. Int J Mol Sci. 2018;19 (4): 923.

54. Anjum FM, Khan MR, Din A, et al. Wheat gluten: high molecular weight glutenin subunits-structure, genetics, and relation to dough elasticity. J Food Sci. 2007;72(3):R56-R63. doi:10.1111/ j.1750-3841.2007.00292.x

55. Wang Z, Li Y, Yang Y, et al. New insight into the function of wheat glutenin proteins as investigated with two series of genetic mutants. Sci Rep. 2017;7(1):3428. doi:10.1038/s41598-01703393-6

56. Wang D, Zhang K, Dong L, et al. Molecular genetic and genomic analysis of wheat milling and end-use traits in China: progress and perspectives. Crop J. 2018;6(1):68-81. doi:10.1016/j.cj.2017.10.001

57. Caminero A, McCarville JL, Galipeau HJ, et al. Duodenal bacterial proteolytic activity determines sensitivity to dietary antigen through protease-activated receptor-2. Nat Commun. 2019;10 (1):1198. doi:10.1038/s41467-019-09037-9

58. Dubé C, Rostom A, Sy R, et al. The prevalence of celiac disease in average-risk and at-risk Western European populations: a systematic review. Gastroenterology. 2005;128(4 Suppl 1): S57-S67. doi:10.1053/j.gastro.2005.02.014

59. Taraghikhah N, Ashtari S, Asri N, et al. An updated overview of spectrum of gluten-related disorders: clinical and diagnostic aspects. BMC Gastroenterol. 2020;20(1):258. doi:10.1186/ s12876-020-01390-0

60. Yoosuf S, Makharia GK. Evolving therapy for celiac disease. Front Pediatr. 2019;7:193. doi:10.3389/fped.2019.00193

61. Asri N, Rostami-Nejad M. The facts of celiac disease; a comprehensive review. Int $J$ Celiac Dis. 2019;7(2):48-52.

62. Asri N, Rostami-Nejad M, Barzegar M, et al. Suppressive mechanisms induced by tregs in celiac disease. Iran Biomed $J$. 2020;24(3):140-147. doi:10.29252/ibj.24.3.140

63. Kårhus LL, Thuesen BH, Skaaby T, et al. The distribution of HLA DQ2 and DQ8 haplotypes and their association with health indicators in a general Danish population. United European Gastroenterol $J$. 2018;6(6):866-878. doi:10.1177/2050640618765506

64. Tye-Din JA, Daveson AJM, Goldstein KE, et al. Patient factors influencing acute gluten reactions and cytokine release in treated coeliac disease. BMC Med. 2020;18(1):362. doi:10.1186/s12916020-01828-y

65. Sharma A, Liu X, Hadley D, et al. Identification of non-HLA genes associated with celiac disease and Country-specific differences in a large, international pediatric Cohort. PLoS One. 2016;11:e0152476. doi:10.1371/journal.pone.0152476

66. Sarno M, Discepolo V, Troncone R, Auricchio R. Risk factors for celiac disease. Ital J Pediatr. 2015;41:57. doi:10.1186/s13052015-0166-y

67. Henderson KN, Tye-Din JA, Reid HH, et al. A structural and immunological basis for the role of human leukocyte antigen DQ8 in celiac disease. Immunity. 2007;27(1):23-34. doi:10.1016/j.immuni.2007.05.015

68. Sollid LM, Tye-Din JA, Qiao SW, et al. Update 2020: nomenclature and listing of celiac disease-relevant gluten epitopes recognized by CD4(+) T cells. Immunogenetics. 2020;72(1-2):85-88. doi:10.1007/s00251-019-01141-w

69. Shan L, Molberg Ø, Parrot I, et al. Structural basis for gluten intolerance in celiac sprue. Science (New York, NY). 2002;297 (5590):2275-2279. doi:10.1126/science.1074129

70. Koning F. Adverse effects of wheat gluten. Ann Nutr Metab. 2015;67(Suppl. 2):7-14. doi:10.1159/000440989

71. Sollid LM, Qiao S-W, Anderson RP, et al. Nomenclature and listing of celiac disease relevant gluten T-cell epitopes restricted by HLA-DQ molecules. Immunogenetics. 2012;64(6):455-460. doi:10.1007/s00251-012-0599-z 
72. Dahal-Koirala S, Risnes LF, Christophersen A, et al. TCR sequencing of single cells reactive to DQ2.5-glia- $\alpha 2$ and DQ2.5-glia- $\omega 2$ reveals clonal expansion and epitope-specific V-gene usage. Mucosal Immunol. 2016;9(3):587-596. doi:10.1038/mi.2015.147

73. Cebolla Á, Moreno M, Coto L, Sousa C. Gluten Immunogenic peptides as standard for the evaluation of potential harmful prolamin content in food and human specimen. Nutrients. 2018;10 (12):1927. doi:10.3390/nu10121927

74. Li D, Jin H, Zhang K, et al. Analysis of the Gli-D2 locus identifies a genetic target for simultaneously improving the breadmaking and health-related traits of common wheat. Plant $J$. 2018;95(3):414-426. doi:10.1111/tpj.13956

75. Schalk K, Lang C, Wieser H, Koehler P, Scherf KA. Quantitation of the immunodominant 33-mer peptide from $\alpha$-gliadin in wheat flours by liquid chromatography tandem mass spectrometry. Sci Rep. 2017;7(1):45092. doi:10.1038/srep45092

76. Zhou L, Kooy-Winkelaar YMC, Cordfunke RA, et al. Abrogation of immunogenic properties of gliadin peptides through transamidation by microbial transglutaminase Is Acyl-acceptor dependent. J Agric Food Chem. 2017;65(34):7542-7552. doi:10.1021/acs. jafc. $7 \mathrm{~b} 02557$

77. Bonciani D, Verdelli A, Bonciolini V, et al. Dermatitis herpetiformis: from the genetics to the development of skin lesions. Clin Dev Immunol. 2012;2012:239691. doi:10.1155/2012/239691

78. Skovbjerg H, Koch C, Anthonsen D, Sjöström H. Deamidation and cross-linking of gliadin peptides by transglutaminases and the relation to celiac disease. Biochim Biophys Acta Mol Basis Dis. 2004;1690(3):220-230. doi:10.1016/j.bbadis.2004.06.009

79. Quarsten H, Molberg O, Fugger L, McAdam SN, Sollid LM. HLA binding and $\mathrm{T}$ cell recognition of a tissue transglutaminase-modified gliadin epitope. Eur $J$ Immunol. 1999;29(8):2506-2514. doi:10.1002/(SICI)1521-4141(199908) 29:08<2506::AID-IMMU2506>3.0.CO;2-9

80. Anderson RP, Degano P, Godkin AJ, Jewell DP, Hill AV. In vivo antigen challenge in celiac disease identifies a single transglutaminase-modified peptide as the dominant A-gliadin T-cell epitope. Nat Med. 2000;6(3):337-342. doi:10.1038/73200

81. Molberg O, McAdam SN, Körner R, et al. Tissue transglutaminase selectively modifies gliadin peptides that are recognized by gut-derived T cells in celiac disease. Nat Med. 1998;4 (6):713-717. doi:10.1038/nm0698-713

82. Arentz-Hansen H, Körner R, Molberg O, et al. The intestinal $\mathrm{T}$ cell response to alpha-gliadin in adult celiac disease is focused on a single deamidated glutamine targeted by tissue transglutaminase. J Exp Med. 2000;191(4):603-612. doi:10.1084/jem.191.4.603

83. Goel G, Tye-Din JA, Qiao S-W, et al. Cytokine release and gastrointestinal symptoms after gluten challenge in celiac disease. Sci $A d v$. 2019;5(8):eaaw7756. doi:10.1126/sciadv. aaw7756

84. Kooy-Winkelaar YMC, Bouwer D, Janssen GMC, et al. CD4 T-cell cytokines synergize to induce proliferation of malignant and nonmalignant innate intraepithelial lymphocytes. Proc Natl Acad Sci. 2017;114(6):E980-E989. doi:10.1073/ pnas. 1620036114

85. Ciccocioppo R, Di Sabatino A, Corazza GR. The immune recognition of gluten in coeliac disease. Clin Exp Immunol. 2005;140 (3):408-416. doi:10.1111/j.1365-2249.2005.02783.x

86. Gianfrani C, Auricchio S, Troncone R. Adaptive and innate immune responses in celiac disease. Immunol Lett. 2005;99 (2):141-145. doi:10.1016/j.imlet.2005.02.017

87. van de Wal Y, Kooy YM, van Veelen P, et al. Glutenin is involved in the gluten-driven mucosal $\mathrm{T}$ cell response. Eur $J$ Immunol. 1999;29(10):3133-3139. doi:10.1002/(SICI)1521-4141(199910) 29:10<3133::AID-IMMU3133>3.0.CO;2-G
88. Barone MV, Troncone R, Auricchio S. Gliadin peptides as triggers of the proliferative and stress/innate immune response of the celiac small intestinal mucosa. Int $J$ Mol Sci. 2014;15 (11):20518-20537. doi:10.3390/ijms151120518

89. Abadie V, Jabri B. IL-15: a central regulator of celiac disease immunopathology. Immunol Rev. 2014;260(1):221-234. doi:10.1111/imr.12191

90. Hardy MY, Tye-Din JA. Coeliac disease: a unique model for investigating broken tolerance in autoimmunity. Clin Transl Immunol. 2016;5(11):e112. doi:10.1038/cti.2016.58

91. Abadie V, Kim SM, Lejeune T, et al. IL-15, gluten and HLA-DQ8 drive tissue destruction in coeliac disease. Nature. 2020;578 (7796):600-604. doi:10.1038/s41586-020-2003-8

92. Dickson BC, Streutker CJ, Chetty R. Coeliac disease: an update for pathologists. $J$ Clin Pathol. 2006;59(10):1008-1016. doi:10.1136/jcp.2005.035345

93. Clarindo MV, Possebon AT, Soligo EM, et al. Dermatitis herpetiformis: pathophysiology, clinical presentation, diagnosis and treatment. An Bras Dermatol. 2014;89(6):865-877. doi:10.1590/ abd1806-4841.20142966

94. Allardyce RA, Shearman DJ. Leukocyte reactivity to alpha-gliadin in dermatitis herpetiformis and adult coeliac disease. Int Arch Allergy Appl Immunol. 1975;48(3):395-400. doi:10.1159/000231324

95. Clark Huff J, Weston WL, Zirker DK. Wheat protein antibodies in dermatitis herpetiformis. J Invest Dermatol. 1979;73(6):570-574. doi:10.1111/1523-1747.ep12541611

96. Catassi C, Fasano A. 1 - Celiac disease. In: Arendt EK, Dal Bello F, editors. Gluten-Free Cereal Products and Beverages. San Diego: Academic Press; 2008:1.

97. Cianferoni A. Wheat allergy: diagnosis and management. $J$ Asthma Allergy. 2016;9:13. doi:10.2147/JAA.S81550

98. Ricci G, Andreozzi L, Cipriani F, et al. Wheat allergy in children: a comprehensive update. Medicina. 2019;55(7):400. doi:10.3390/ medicina55070400

99. Koehler P, Wieser H, Konitzer K. Chapter 1 - Celiac Disease-A Complex Disorder. In: Koehler P, Wieser H, Konitzer K, editors. Celiac Disease and Gluten. Boston: Academic Press; 2014:1-96.

100. Scherf K, Brockow K, Biedermann T, et al. Wheat-dependent exercise-induced anaphylaxis. Clin Exp Allergy. 2015;46.

101. De Santis MA, Giuliani MM, Giuzio L, et al. Differences in gluten protein composition between old and modern durum wheat genotypes in relation to 20th century breeding in Italy. Eur J Agron. 2017;87:19-29. doi:10.1016/j.eja.2017.04.003

102. Hofmann S, Fischer J, Eriksson C, et al. IgE detection to $\alpha / \beta / \gamma$ gliadin and its clinical relevance in wheat-dependent exerciseinduced anaphylaxis. Allergy. 2012;67:1457-1460. doi:10.1111/ all. 12020

103. Morita E, Matsuo H, Mihara S, et al. Fast $\omega$-gliadin is a major allergen in wheat-dependent exercise-induced anaphylaxis. J Dermatol Sci. 2003;33(2):99-104. doi:10.1016/s0923-1811(03) 00156-7

104. Palosuo K, Alenius H, Varjonen E, Kalkkinen N, Reunala T. Rye $\gamma-70$ and $\gamma-35$ secalins and barley $\gamma-3$ hordein cross-react with $\omega-5$ gliadin, a major allergen in wheat-dependent, exercise-induced anaphylaxis. Clin Exp Allergy. 2001;31(3):466-473. doi:10.1046/j.1365-2222.2001.01023.x

105. Kennard L, Thomas I, Rutkowski K, et al. A multicenter evaluation of diagnosis and management of omega-5 gliadin allergy (Also known as wheat-dependent exercise-induced anaphylaxis) in 132 adults. $J$ Allergy Clin Immunol Pract. 2018;6 (6):1892-1897. doi:10.1016/j.jaip.2018.02.013

106. Sandiford CP, Tatham AS, Fido R, et al. Identification of the major water/salt insoluble wheat proteins involved in cereal hypersensitivity. Clin Exp Allergy. 1997;27(10):1120-1129. doi:10.1111/j.1365-2222.1997.tb01148.x 
107. Baar A, Pahr S, Constantin C, et al. Molecular and immunological characterization of Tri a 36, a low molecular weight glutenin, as a novel major wheat food allergen. $J$ Immunol. 2012;189:3018-3025. doi:10.4049/jimmunol.1200438

108. Galli SJ, Tsai M. IgE and mast cells in allergic disease. Nat Med. 2012;18(5):693-704. doi:10.1038/nm.2755

109. Volta U, Caio G, Tovoli F, De Giorgio R. Non-celiac gluten sensitivity: questions still to be answered despite increasing awareness. Cell Mol Immunol. 2013;10(5):383-392. doi:10.1038/cmi.2013.28

110. Rostami K, Hogg-Kollars S. A patient's journey. non-coeliac gluten sensitivity. BMJ. 2012;345:e7982. doi:10.1136/bmj.e7982

111. Rostami-Nejad M, Lahmi F, Zali M. Non-celiac Gluten Sensitivity. J Army Univ Med Sci. 2013;11:243-251.

112. Catassi C, Alaedini A, Bojarski C, et al. The overlapping area of non-celiac gluten sensitivity (NCGS) and wheat-sensitive irritable bowel syndrome (IBS): an update. Nutrients. 2017;9(11):1268. doi:10.3390/nu9111268

113. Ierardi E, Losurdo G, Piscitelli D, et al. Biological markers for non-celiac gluten sensitivity: a question awaiting for a convincing answer. Gastroenterol Hepatol Bed Bench. 2018;11(3):203-208.

114. Losurdo G, Piscitelli D, Pezzuto F, et al. T helper lymphocyte and mast cell immunohistochemical pattern in nonceliac gluten sensitivity. Gastroenterol Res Pract. 2017;2017:5023680. doi:10.1155/2017/5023680

115. Sapone A, Lammers KM, Casolaro V, et al. Divergence of gut permeability and mucosal immune gene expression in two gluten-associated conditions: celiac disease and gluten sensitivity. BMC Med. 2011;9(1):23. doi:10.1186/1741-7015-9-23

116. Barbaro MR, Cremon C, Stanghellini V, Barbara G. Recent advances in understanding non-celiac gluten sensitivity. F1000Res. 2018;7: F1000Faculty Rev-1631. doi:10.12688/f1000research.15849.1

117. Catassi C, Elli L, Bonaz B, et al. Diagnosis of non-celiac gluten sensitivity (NCGS): the Salerno experts' criteria. Nutrients. 2015;7(6):4966-4977. doi:10.3390/nu7064966

118. Ortiz C, Valenzuela R, Lucero AY. [Celiac disease, non celiac gluten sensitivity and wheat allergy: comparison of 3 different diseases triggered by the same food]. [Spanish]. Rev Chil Pediatr. 2017;88(3):417-423. doi:10.4067/S0370-41062017000300017

119. Tye-Din JA, Skodje GI, Sarna VK, et al. Cytokine release after gluten ingestion differentiates coeliac disease from self-reported gluten sensitivity. United European Gastroenterol J. 2020;8 (1):108-118. doi:10.1177/2050640619874173

120. Uhde M, Caio G, De Giorgio R, et al. Subclass profile of IgG antibody response to gluten differentiates nonceliac gluten sensitivity from celiac disease. Gastroenterology. 2020;159(5):19651967.e2. doi:10.1053/j.gastro.2020.07.032

121. Vojdani A, Perlmutter D. Differentiation between celiac disease, nonceliac gluten sensitivity, and their overlapping with Crohn's disease: a case series. Case Rep Immunol. 2013;2013:248482. doi: $10.1155 / 2013 / 248482$

122. Skodje GI, Sarna VK, Minelle IH, et al. Fructan, rather than gluten, induces symptoms in patients with self-reported non-celiac gluten sensitivity. Gastroenterology. 2018;154 (3):529-539.e522. doi:10.1053/j.gastro.2017.10.040

123. Daveson AJM, Tye-Din JA, Goel G, et al. Masked bolus gluten challenge low in FODMAPs implicates nausea and vomiting as key symptoms associated with immune activation in treated coeliac disease. Aliment Pharmacol Ther. 2020;51(2):244-252. doi:10.1111/apt.15551

124. El Khoury D, Balfour-Ducharme S, Joye IJ. A review on the gluten-free diet: technological and nutritional challenges. Nutrients. 2018;10(10):1410. doi:10.3390/nu10101410

125. Rostami K, Bold J, Parr A, Johnson MW. Gluten-free diet indications, safety, quality, labels, and challenges. Nutrients. 2017;9 (8):846. doi:10.3390/nu9080846
126. Jouanin A, Gilissen LJWJ, Schaart JG, et al. CRISPR/Cas9 gene editing of gluten in wheat to reduce gluten content and exposure-reviewing methods to screen for coeliac safety. Front Nutr. 2020;7:51. doi:10.3389/fnut.2020.00051

127. Jouanin A, Schaart JG, Boyd LA, et al. Outlook for coeliac disease patients: towards bread wheat with hypoimmunogenic gluten by gene editing of $\alpha$ - and $\gamma$-gliadin gene families. $B M C$ Plant Biol. 2019;19(1):333. doi:10.1186/s12870-019-1889-5

128. Borisjuk N, Kishchenko O, Eliby S, et al. Genetic modification for wheat improvement: from transgenesis to genome editing. Biomed Res Int. 2019;2019:6216304. doi:10.1155/2019/621 6304

129. Li H, Yang Y, Hong W, Huang M, Wu M, Zhao X. Applications of genome editing technology in the targeted therapy of human diseases: mechanisms, advances and prospects. Signal Transduct Target Ther. 2020;5(1):1.

130. Wang K, Riaz B, Ye X. Wheat genome editing expedited by efficient transformation techniques: progress and perspectives. Crop J. 2018;6(1):22-31. doi:10.1016/j.cj.2017.09.009

131. Vasil V, Castillo AM, Fromm ME, Vasil IK. Herbicide resistant fertile transgenic wheat plants obtained by microprojectile bombardment of regenerable embryogenic callus. Bio/Technology. 1992;10(6):667-674.

132. Agrawal N, Dasaradhi PVN, Mohmmed A, et al. RNA interference: biology, mechanism, and applications. Microbiol Mol Biol Rev. 2003;67(4):657-685. doi:10.1128/MMBR.67.4.657685.2003

133. Tenea G, Burlibasa L. RNAi Towards Functional Genomics Studies. InTech Publisher. 2012:67-94.

134. Ansari WA, Chandanshive SU, Bhatt V, et al. Genome editing in cereals: approaches, applications and challenges. Int J Mol Sci. 2020;21(11):4040. doi:10.3390/ijms21114040

135. Travella S, Klimm TE, Keller B. RNA interference-based gene Silencing as an efficient tool for functional genomics in hexaploid bread wheat. Plant Physiol. 2006;142(1):6-20. doi:10.1104/ pp.106.084517

136. Gil-Humanes J, Pistón F, Altamirano-Fortoul R, et al. Reducedgliadin wheat bread: an alternative to the gluten-free diet for consumers suffering gluten-related pathologies. PLoS One. 2014;9(3):e90898. doi:10.1371/journal.pone.0090898

137. Altenbach SB, Tanaka CK, Seabourn BW. Silencing of omega-5 gliadins in transgenic wheat eliminates a major source of environmental variability and improves dough mixing properties of flour. BMC Plant Biol. 2014;14(1):393. doi:10.1186/s12870-0140393-1

138. Altenbach SB, Chang H-C, Rowe MH, et al. Reducing the immunogenic potential of wheat flour: silencing of alpha gliadin genes in a U.S. wheat cultivar. Front Plant Sci. 2020;11(20). doi:10.3389/fpls.2020.00020.

139. Barro F, Iehisa J, Gimenez M, et al. Targeting of prolamins by RNAi in bread wheat: effectiveness of seven silencing-fragment combinations for obtaining lines devoid of coeliac disease epitopes from highly immunogenic gliadins. Plant Biotechnol J. 2015;14. doi:10.1111/pbi.12455

140. Ervin E-H, Pook M, Teino I, et al. Targeted gene silencing in human embryonic stem cells using cell-penetrating peptide PepFect 14. Stem Cell Res Ther. 2019;10(1):43. doi:10.1186/ s13287-019-1144-x

141. Gaj T, Gersbach CA, Barbas CF 3rd ZFN, TALEN, and CRISPR/Cas-based methods for genome engineering. Trends Biotechnol. 2013;31(7):397-405. doi:10.1016/j.tibtech.2013. 04.004

142. Deshpande K, Vyas A, Balakrishnan A, Vyas D. Clustered regularly interspaced short palindromic Repeats/Cas9 genetic engineering: robotic genetic surgery. Am J Robot Surg. 2015;2 (1):49-52. doi:10.1166/ajrs.2015.1023 
143. Campenhout CV, Cabochette P, Veillard A-C, et al. Guidelines for optimized gene knockout using CRISPR/Cas9. BioTechniques. 2019;66(6):295-302. doi:10.2144/btn-2018-0187

144. Hsu PD, Lander ES, Zhang F. Development and applications of CRISPR-Cas9 for genome engineering. Cell. 2014;157 (6):1262-1278. doi:10.1016/j.cell.2014.05.010

145. Shan Q, Wang Y, Li J, et al. Targeted genome modification of crop plants using a CRISPR-Cas system. Nat Biotechnol. 2013;31 (8):686-688. doi:10.1038/nbt.2650

146. Sánchez-León S, Gil-Humanes J, Ozuna CV, et al. Low-gluten, nontransgenic wheat engineered with CRISPR/Cas9. Plant Biotechnol J. 2018;16(4):902-910. doi:10.1111/pbi.12837
147. Jouanin A, Borm T, Boyd LA, et al. Development of the GlutEnSeq capture system for sequencing gluten gene families in hexaploid bread wheat with deletions or mutations induced by $\gamma$-irradiation or CRISPR/Cas9. J Cereal Sci. 2019;88:157-166. doi:10.1016/j.jcs.2019.04.008

148. Purnhagen K, Wesseler J. EU regulation of new plant breeding technologies and their possible economic implications for the EU and beyond. Appl Econ Perspect Policy. 2020:1-17.

\section{Publish your work in this journal}

The Application of Clinical Genetics is an international, peerreviewed open access journal that welcomes laboratory and clinical findings in the field of human genetics. Specific topics include: Population genetics; Functional genetics; Natural history of genetic disease; Management of genetic disease; Mechanisms of genetic disease;
Counselling and ethical issues; Animal models; Pharmacogenetics; Prenatal diagnosis; Dysmorphology. The manuscript management system is completely online and includes a very quick and fair peerreview system, which is all easy to use. Visit http://www.dovepress. com/testimonials.php to read real quotes from published authors. 